\title{
City architecture from traditional past - a Malaysian case
}

\author{
A. B. Sulaiman \& S. Shamsuddin \\ Universiti Teknologi Malaysia, Kuala Lumpur, Malaysia
}

\begin{abstract}
Traditional city-forms that still exist today reflect a civilization from which a designer for future sustainable settlements could learn - by looking at its strengths and weaknesses. The traditional form in Malaysia produces city architecture that is still vibrant today. It was formed by modifying and adapting existing situations to meet the needs, as well as the aspirations, of the people that have resulted in a unique and distinctive urban ensemble. Through time the city architecture represents the broader context of the society. This is in contrast to the modern building and urban architecture that lacks environmental, cultural, psychological and behavioural responses. The current practices (Malaysia) through simplistic application of planning, social, economic and environmental theories, produces towns and cities that lack identity. The human scale and sense of unity of the traditional settlements creates an urban composition that is unique and readily recognizable, and assist in creating a clear sense of place. There is a rich discourse between the public realm, with individual territorial needs in a complex and compact existence, which create a townscape character that displays a rich and harmonious ethnic composition that could inform designer in creating future places. The facilities they provide also shows their response to the individual and public needs of a sustainable and liveable city.
\end{abstract}

Keywords: city architecture, liveable city, sustainable urban design.

\section{Introduction}

Many different cities have evolved through time, responding to the needs of man, such as those associated with culture, commerce, industry, power and others. But most of all, cities are places where people live, where it is possible to fulfill ones desires, aspirations and needs. Thus a city should be a place for work, 
for bring up family, for education, for expression (public and private), for enjoyment and others associated with life and our sense of existence. It is a setting for human interaction at various levels that requires spaces and places that are associated with it, which have meaning to the users. With all these expectations, a city has to be sustainable (endeavour to preserve and improve the environmental health of people and natural system, see Watson [1]).

The problem with modern towns/cities in Malaysia is the trend to compartmentalise the settlement into different areas. These include regions such as a commercial area, an administrative centre, a residential area, an industrial area and others. This resulted in the emergence of administrative city, education city, historic city and other brand names. The effort of re-branding and marketing in order to attract visitors and investment may have skewed the original image of a city as a place for human settlement. The emergence of international cities like Dubai, Singapore, Shanghai and others has raised issues relating to local character as in international style of architecture - the architecture of everywhere and nowhere. In Malaysia the erosion of liveable places within the city has mostly occurred by getting rid of the places that generate traffic congestion such as schools, market places, nodes (mosque, bus station) and others that resulted in the towns and cities (especially the centres) becoming less attractive as a place to live.

Looking at the old towns it is possible to see successful, sustainable solutions that would give ideas for future direction. They will also give clues to the problems or misfits associated with urban spaces and form. In many cities that are populated by many different ethnic groups, age and religious belief like Malacca, Georgetown, Kuching, Kuantan and others, there are many lessons that could be modeled from their successes and failures. These are living cities that are successful in meeting the various needs of the people (i.e. sustainable) and still relevant today. In fact current efforts in encouraging people to live in the city (recently in Malaysia) are what our forefathers have been doing successfully before.

The main concern is to create cities that have a clear sense of place based on commodity, firmness and delight (Vitruvius during Augustus reign). Worskett [2] suggested that the old settlements were noted for their ability to express the essence of what each city is and how it differs from another (unique). The aspects of the environment that could be modeled from the traditional towns/cities are based on the physical, psychological, social and behavioral character that emerged as a unique ensemble that makes the city livable and identifiable (see also Moughtin [3], Canter [4], Tibbalds [5], Down and Stea [6] and Relph [7]).

The method adopted in the study is looking at the various components of the town (using techniques as suggested by Lynch, Cullen, Rapoport, Moughtin etc.), and identifying their attributes relating to their strength and weaknesses. These are their ability to support the uses, the image that they portray through visual composition, clarity of the structure, ability to support different activities and adaptability. The assessment also looks at the core aspects or attributes that indicate the robustness of the ensemble. At the same time the changeable 
structure of the component will be identified as possibilities for future adaptation. All these can be developed into a sustainable design of livable towns of the future.

\section{The traditional old towns}

The traditional towns of Malaysia such as Malacca (one of the oldest cities, making a significant contribution to the world's history through its role as an important trading port in the $15^{\text {th }}$ century), Georgetown (Penang), Kuching (Sarawak) and others are some of the examples that could be used as a model. The place evolves by responding to the needs of the people and sometimes through the aspiration of their leaders. Many of the towns experience a succession of past masters from the Malay Sultanate period (Melaka, Kuala Trengganu, Kota Bahru, Pekan, etc.), the Portuguese (Melaka), the Dutch (Melaka), the British (Melaka, Georgetown, Taiping, Kuching etc.) and the postcolonial period of independence (Kuantan, Johor Bahru, etc.), that inscribe their print on the scroll of its evolution.

The Malay Sultanate sets the early foundation for the urban pattern that shapes the historic core of a living city in Malaysia. This is evident in the morphology where a palace, associated government offices and other support facilities (such as the artisan), mosque, the nobility, residential quarters, commercial complex and the bazaars are within close proximity (Melaka, Kuala Trengganu, Kota Bahru, Pekan and others). At the same time the introduction of shop-houses (Kuala Lumpur, Taiping, Melaka, George Town, etc.) where one is able to engage in retail activities and living in the upper floors create a vibrant urban neighbourhood that respond to the need for public engagement and a sanctuary for bringing up a family.

\section{Socio-cultural aspects}

The users of most modern cities consist of many different ethnic, religious and age groups. In Malaysia the population is based on the three major ethnic groups the Malay, Chinese and Indian with others (such as European, Middle-Eastern, African, etc.) making up the rest. Traditionally, these different groups work and live within the city boundary in a clearly recognizable district or cluster. Within each cluster, there will be a place of worship that reflects the faith of the particular ethnic group. The compact urban fabric results in the close proximity of this cluster as in the case of Jalan To'kong (Melaka) and Jalan Kapitan Kling (Penang), three different types of places of worship belonging to the three different ethnic groups can be found located within one street.

These places of worship are the center of the community, for example, the mosque is a place for learning, social gathering, celebrations, funerals, weddings and others where it is located strategically. This ensures the sustainability of the old town from the socio-cultural point of view.

The settlement (streets and squares) that consisted of workplaces and residential units produces a unique architectural typology known as the 'shop- 
house'. It comprises of rows of terraced buildings (single or multiple stories) that accommodate business and living activities. The ground level (main street frontages) of the building is for commercial activities whilst the major part of the back portion and the upper levels are for residential areas. This vertical/horizontal segregation of use is more sustainable. Thus a unique blend of retail and residential character can be seen. The design of the newer city centres tend to focus on commercial developments that consist of shop-offices where offices or storage are located upstairs.

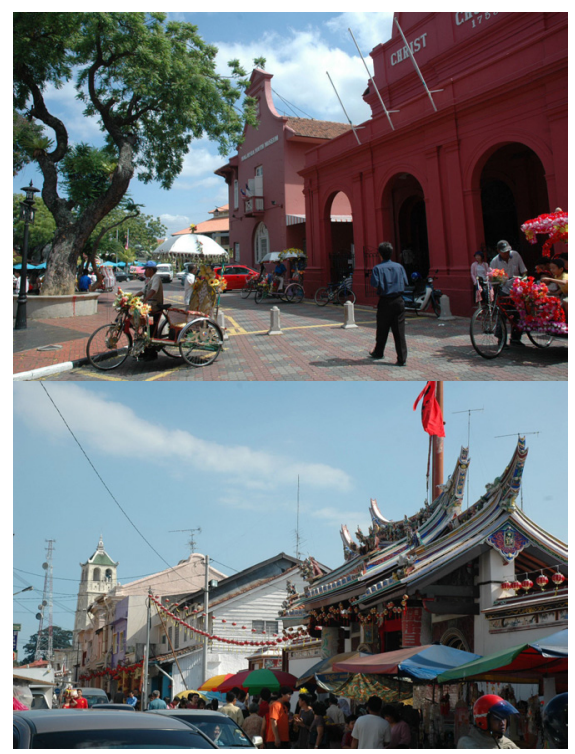

Figure 1: Religion is one of the most visible aspects of the social-cultural attributes.
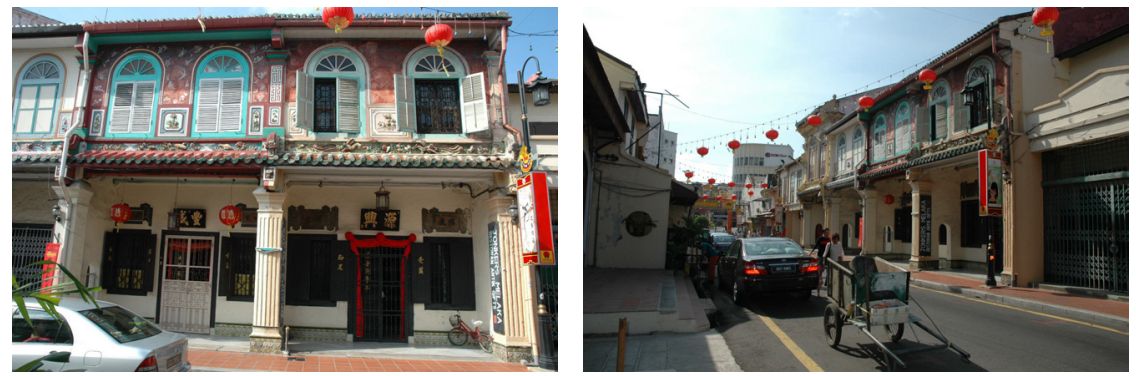

Figure 2: $\quad$ Individuality and neighbourhood.

The Melaka 'shop-house' design is unique, where the street frontage is narrow allowing larger number of unit per street length and elongated backwards. Courtyard(s) are used for better ventilation and light quality (in many cases when the lot is extra long there are a series of courtyards). 


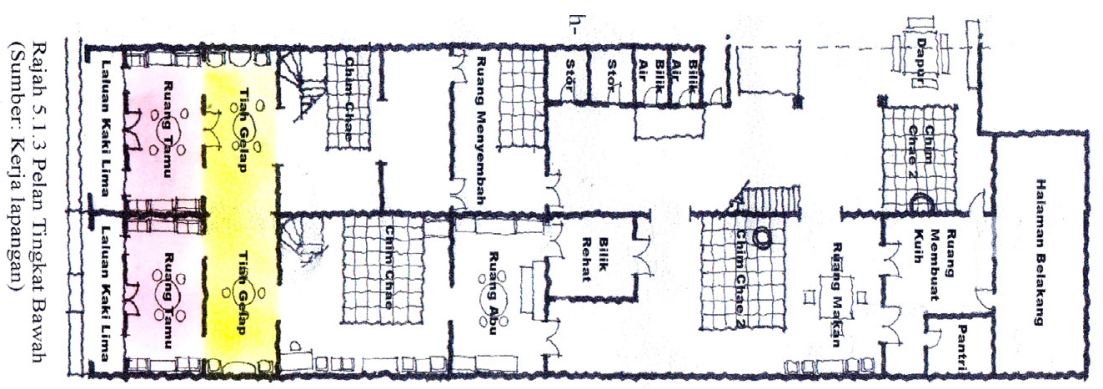

Figure 3: The plan of a typical Melaka shop house.

Finally, the traditional towns and cities also have schools located within the central areas that add character to the place where existence of children playing and the size of the school compound increases its vitality.

\section{Functional character}

It has been acknowledged that forms and images of towns reflect the activity settings they provide. Commercial, administrative centers and residential function can be found in many towns that have responded to the emergence of different settings for the function. In some cases the name of the street reflects the dominant activities for example (Melaka) Jalan Tukang Emas (Goldsmith Street) and Jalan Tukang Besi (Ironmonger Street) that strengthen its identity and sense of place.

The arcaded walkway ('five foot walkway'), allows shopkeepers to display their merchandise, which increases the transparency of these buildings. For restaurants, dining and the food preparation are done in this area too or sometime on the street itself. The aroma of the food, the sound and the sense of color fills the space that enriches the experience where outdoor eating places are common in tropical climates.
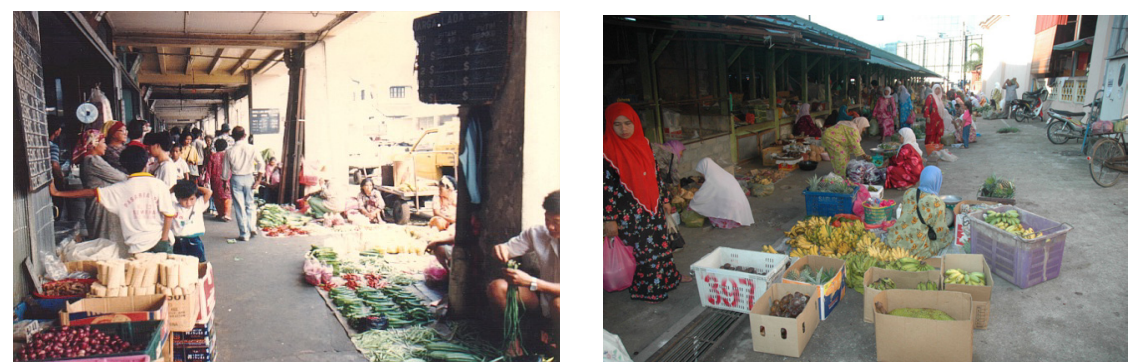

Figure 4: Arcaded walkway: setting for activities, Jalan Gambir, Kuaching, Sarawak and market place, Kota Bahru. 
Multiplicity of use also characterizes the old town form where the mixing of work and living places is an old trend that could contribute greatly to the character of newer or future development where towns are seen as a setting for human settlement that must fulfill mans' every needs.

\section{Physical aspects}

Physically the traditional towns are very rich with townscape character that makes them memorable and conducive for living. The urban spaces are adorned with buildings and ornaments that reflects the function of the place displaying their aesthetic quality for everyone to enjoy.

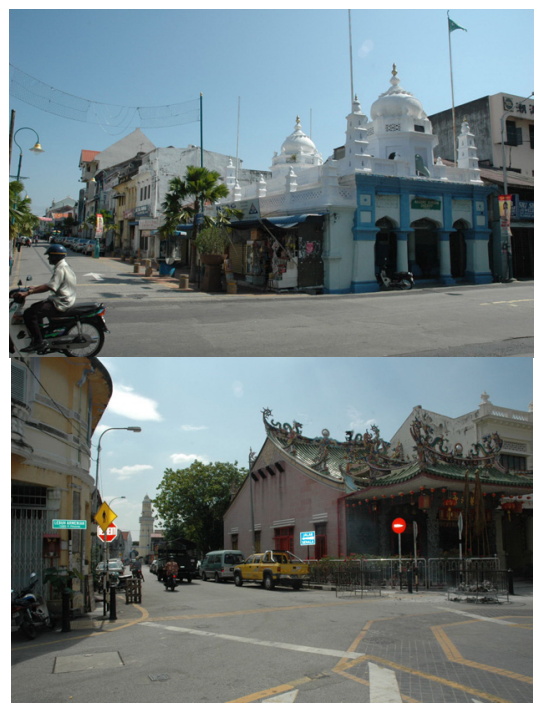

Figure 5: Chinese Temple and Mosque, Georgetown.

\section{Privacy and the community}

The deep plan on the other hand provides a lot of privacy where the internal courtyard offers a safe haven to relieve stress for the dwellers. It acts as an indoor garden where an outdoor environment can be experienced in complete privacy. Sometime the privacy (e.g. Jalan Tun Tan Cheng Lock (Melaka)) is secured by the blocked arcaded walkway. The resident enjoys a semi-public space in front of their town house for the purpose of socialization as well as acting as setting to the house.

The community centers (mosque, temple, community hall, etc.) usually located within the residential or shopping street that makes it easily accessible. In some cases even public performances were done in the street.

The irregular street together with the more familiar gridiron pattern produces unique visual experiences with clever juxtaposition of buildings or minaret 
towers as focal points. The narrow streets give a strong sense of enclosure and intimacy that lends to a sense of community, as well as a sense of safety as one can observe the activities opposite. The modern street pattern tends to severe the place into two sides, alienated from each other.
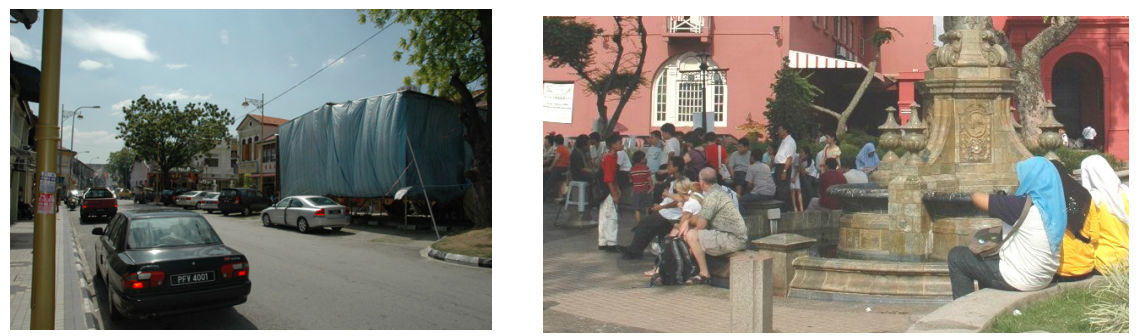

Figure 6: $\quad$ Street as setting for public performance.
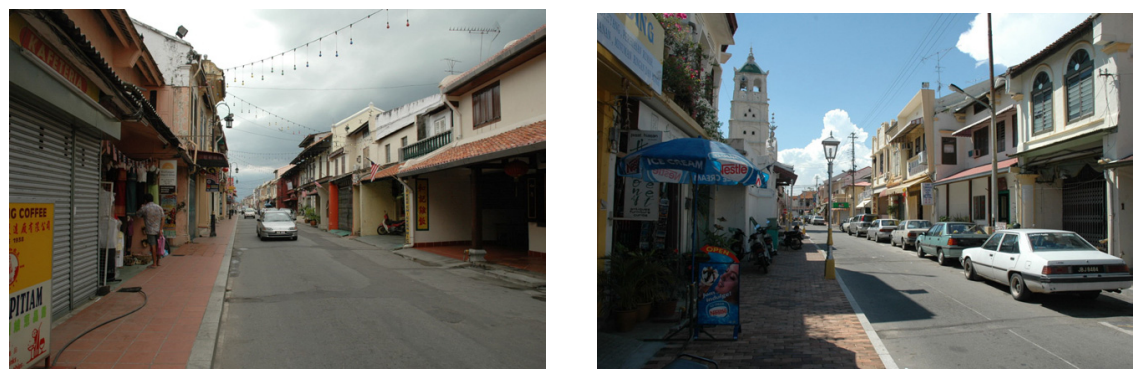

Figure 7: High density and mix-uses (private, public and commercial activities).
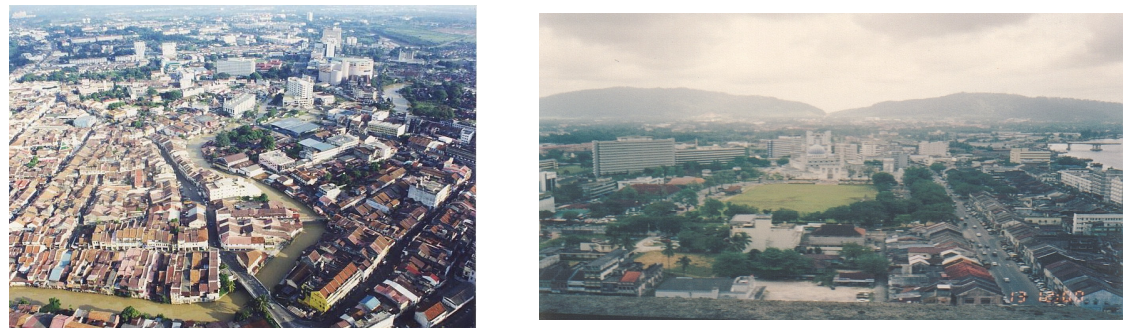

Figure 8: The traditional urban form of 'The Historical City of Melaka' and Kuantan.

\section{Conclusion}

This paper has highlighted the qualities that make the traditional towns and cities (like Melaka, Georgetown, Kuantan, etc.) an excellent model of a sustainable city for the future. It examines these qualities from three broad aspects that are the socio-cultural attributes, the functional and behavioural attributes and the 
physical attributes. The urban form of the traditional ensemble displayed an interesting pattern of urban living that integrate the essential parts of life (social cultural activities etc.) within a given place that support the needs in terms of design. The integrated/mixed uses succeeded in creating a close knit community that is inter-dependent on each other in their daily routine. Such a scenario makes the city more sustainable as the urban form is more compact with maximum use of resources (land) and efficient infrastructure. Pollution and use of energy will also be reduced due to less dependence on motorised vehicular transportation. The problem of urban sprawl that that often affects modern cities in the developing nations can also be avoided. The compact approach managed to create sense of vitality and viability where the mix of use generated interesting ambience with rich character that responded to the activities.

Whilst the current trend of city planning and design with its regulations tends to produce a straight jacket, characterless international or global cities that are highly dependent on motorised vehicles for transportation with buildings and spaces that barely represent the locality. There needs to be some serious rethinking of how future cities should be designed so that is not just for image, form making and commercial activities but also as a place to live. In this globalisation age and energy conscious era there is a tendency to design towns and cities based on technical expectation alone. The attributes of the model developed based on the traditional cities can be seen as a way in which the design and planning of the cities can be made sustainable by creating a living city that enables the community to function effectively and allowing for the fostering of cultural values that create the sense of place for the future cities in Malaysia.

\section{References}

[1] Watson D, eds., 2003, Time Saver Standards for Urban Design, McGraw Hill, New York.

[2] Worskett, 1969, The Character of Towns, Architectural Press, London.

[3] Moughtin JC, 1992, Urban Design: Streets and Square, Butterworth.

[4] Canter D, 1977, The Psychology of Place, The Architectural Press, London.

[5] Tibbalds F (2001) Making people friendly towns, Spon Press.

[6] Downs R. M. and Stea D. (eds.), 1973, Image and Environment - Cognitive Mapping and Spatial Behaviour, Edward Arnold (Pub.) Ltd., London.

[7] Relph E, 1976, Place and Placelessness, Pion Limited, London. 